\title{
Nursing diagnoses and NIC interventions in adult males undergoing radical prostatectomy
}

\author{
Diagnósticos de Enfermagem e intervenções NIC em adultos do \\ sexo masculino que passaram por prostatectomia radical \\ Diagnósticos de Enfermería e intervenciones NIC en adultos del \\ sexo masculino que pasaron por prostatectomía radical
}

How to cite this article:

Kocaçal E, Karadağ E. Nursing diagnoses and NIC interventions in adult males undergoing radical prostatectomy. Rev Esc Enferm USP. 2020;54:e03541. DOI: http://dx.doi.org/10.1590/S1980-220X2018038003541

\section{Elem Kocaçal ${ }^{1}$}

Ezgi Karadağ ${ }^{1}$

${ }^{1}$ İzmir Demokrasi University, Faculty of Health Sciences, Department of

Fundamentals of Nursing, İzmir, Turkey.

${ }^{2}$ Dokuz Eylül University Faculty of Nursing, Department of Oncology Nursing, İzmir, Turkey.

\begin{abstract}
Objective: To determine NANDA-I nursing diagnoses and NIC nursing interventions in patients who underwent radical prostatectomy. Method: A cross-sectional and descriptive study was conducted in a research and teaching hospital in western Turkey between June 2016 and June 2017. The sample included adult patients diagnosed with prostate cancer in the immediate postoperative period of radical prostatectomy. Data collection was performed using Gordon's Functional Health Patterns, NANDA-International and Nursing Interventions Classification Taxonomy Systems. Results: Participants were 54 adult patients. The main nursing diagnoses were in the classes of "physical injury", "selfcare", "hydration" and "physical comfort". Some nursing diagnoses were identified in all patients, namely: "risk for deficient fluid volume", "risk for imbalanced fluid volume", "impaired urinary elimination". The most selected NIC interventions were in the classes of "risk management", "elimination management", "coping assistance", "tissue perfusion management" and "self-care facilitation". Conclusion: future studies with larger populations are needed to explore the nursing diagnoses and effects of nursing interventions on patients who underwent radical prostatectomy.
\end{abstract}

DESCRIPTORS

Prostatectomy; Classification; Nursing Process; Nursing Diagnosis; Oncology Nursing.

\section{Corresponding author:}

Elem Kocaçal

İzmir Demokrasi University,

Faculty of Health Sciences

Department of Nursing, Üçkuyular

District, Gürsel Aksel St., 14

35140 - Karabağlar, İzmir, Turkey

elem.kocacalguler@idu.edu.tr 


\section{INTRODUCTION}

Nearly 1.1. million men received a diagnosis of prostate cancer (Pca) around the world in 2012. Most cases were seen in more developed countries and the highest incidence rates were found in Australia and New Zealand, North America, and Western and Northern Europe. In Turkey, an epidemiological study was carried out by the Uro-oncology Association of Turkey to determine the incidence of Pca in the Turkish population. Findings obtained from the 12 cities selected showed 6,693 cases were registered. In addition, the incidence rate of age-related Pca was $\sim 36$ per 100,000, similar to other north Mediterranean countries ${ }^{(1-2)}$.

The choice of Pca treatment depends on the cancer severity, age, general health, life expectancy, as well as the patient's and the physician's preference. "In localized stages, radiotherapy or radical prostatectomy (RP) surgery, either by a conventional open approach or laparoscopy, is considered optional"(3). Radical prostatectomy is often accompanied by bilateral pelvic lymph-node dissection and "involves removal of the entire prostate gland and resection of both seminal vesicles with sufficient surrounding tissue to obtain a negative margin" ${ }^{(4)}$. This approach is the most often preferred surgical treatment applied to those aged over 65 years and in cases of Pca with a 10-year life expectancy ${ }^{(5-6)}$.

Although RP is considered the gold standard in Pca and has a low morbidity rate when performed at a suitable stage, it can lead to complications such as bleeding, rectal injury, deep vein thrombosis, shock and pulmonary embolism in the early stages, and to anastomotic stricture, urinary incontinence and erectile dysfunction in the late stages. Therefore, maintaining quality of life (QOL) in the postoperative period by preventing complications is fundamental ${ }^{(4-5,7-9)}$.

Patients undergoing RP can have their QOL increased through comprehensive nursing based on a systematically prepared nursing process. NANDA-I nursing diagnoses (NDs) is an important classification system, and its definition is the first stage and key component of the nursing process ${ }^{(10-14)}$. Nursing Interventions Classification (NIC) is another classification system. It enables the determination, naming and identification of actions taken towards the preservation and improvement of individual, family and community health and all coordinated and independent interventions of nurses in accordance with the determined $\mathrm{NDs}^{(11,14-15)}$.

Scanning the literature, most studies conducted in Turkey with patients undergoing $\mathrm{RP}$ were focused on the frequent difficulties and complications arising in late stages. In addition, was found no study exploring both NDs and NICs together in this patient group worldwide. Thus, a systematic nursing evaluation based on a classification system with a holistic approach in the early postoperative period will prevent the omission of many problems while showing patients' difficulties. Such an evaluation will also facilitate the prevention and management of eventual complications occurring after discharge. Therefore, the aim of the study was to determine NANDA-I ND and NIC interventions in patients admitted to the urology clinic who underwent RP.The result of the study included a review of the problems of patients undergoing $\mathrm{RP}$, and the identification of priority fields in nursing care. In addition, given the importance of using a common language in nursing, these findings will form a basis for further descriptive and interventional studies on NDs and classification systems in nursing. The development of this study will also enable international comparisons regarding this topic between Turkey and other countries.

\section{METHOD}

\section{Design OF STUDY}

This cross-sectional and descriptive study was conducted in the urology clinic of a research and teaching hospital in western Turkey between June 2016 and June 2017. This clinic has 29 beds and is one of the largest units in the region. Adult patients with medical diagnoses such as benign prostate hyperplasia, kidney stones, Pca and bladder cancer are treated there. Nine nurses work in the unit.

\section{SAMPLE DEFINITION}

Participants were 54 adult patients diagnosed with Pca in the immediate postoperative period (first 24-72 hours after the surgical procedure). The inclusion criteria were being in the immediate postoperative period of RP between June 2016 and June 2017, over 18 years of age, and participating in the study voluntarily. Patients under 18 years of age and those unwilling to take part in the study were excluded.

\section{Data collection}

Data collection was carried out by physical assessment, examination of patients' records, observation, and face-to-face interview with patients. The follow-up period was four days after the surgery, determined based on a laparoscopic $\mathrm{RP}$ operation and the 2-4 day discharge period stated in the literature ${ }^{(4,16)}$.

A data collection form in line with a comprehensive review of literature was prepared by researchers. The form consisted of Gordon's Functional Health Patterns (FHP), sociodemographic features and postoperative assessments of patients ${ }^{(4-5,10,16-17)}$. The FHP method was developed by Marjory Gordon $^{(18)}$ and is used by nurses in the nursing process for a comprehensive nursing assessment of patients. The system includes 11 categories. In addition to the FHP, the data collection form included five sociodemographic items (age, marital status, occupation, educational level, income level) and 16 items of postoperative assessments (e.g. vital signs, level of consciousness, fluid balance, capillary refill time, oxygen saturation, infusion rates, surgical site and laboratory test results).

Expert opinion (five nurse academics teaching and studying nursing taxonomy and classification systems, three nurses experienced in urology clinic, two nurses experienced in surgical ward) was received for content validity assessment. The content was approved based on expert judges' suggestions. A pilot study with a 3-day interval was also conducted with 12 patients who underwent RP surgery in the urology unit for assessment of the form reliability, but these patients were excluded from the main study. Cronbach's alpha for the pilot study was $0.924(\mathrm{p}=0.002)$. 
The NDs were determined using the English ${ }^{(13)}$ and Turkish $^{(19)}$ versions of NANDA-I 2015-2017 nursing diagnoses. The taxonomy II ND system is based on Gordon's FHP and includes 13 domains and 47 classes. In this sense, our data collection form consisting of the FHP and sociodemographic and postoperative data, included all diagnostic clues (defining characteristics and risk factors) for the judgement of nursing diagnoses. Nursing interventions based on the NDs were identified according to the taxonomy of both English ${ }^{(11)}$ and Turkish ${ }^{(20)}$ versions of the Nursing Interventions Classification reference book (Iowa University). The NIC taxonomy structure consists of seven domains (physiological, basic; physiological, complex; behavioural; safety; family; health system and community), 30 classes and 565 nursing interventions.

Standardized nursing languages were not already a part of the nursing care at the urology unit where the study was conducted. On the other hand, in Turkey, classification systems, especially the nursing process and NANDA-I NDs, are well-known among nurse academics and students. They have been taught in nursing students' training and used during their internship programs since the beginning of year 2000. NANDA-I NDs and NICs are planned to be used by nurses in all Turkish hospitals in a near future. Some nursing law regulations indicate their use in nursing processes will be mandatory for nursing care.

After collecting data from patients, each researcher independently selected the NDs and applicable NIC interventions based on the NDs identified. Researchers used the defining characteristics, related factors and risk factors in the data collection form as guidance to decide a nursing diagnosis. In line with the literature, they considered the presence of at least one major defining characteristic and related factor for deciding an actual nursing diagnosis independently. For the decision of risk diagnoses, researchers considered the presence of risk factors ${ }^{(13)}$. The Cohen's kappa $(\kappa)$ test was used to determine the consistency between two researchers. In the final phase, authors reached a consensus on NDs and NIC interventions. The first author has publications on ND, and the second author teaches in the Oncology Nursing specialisation course. Both authors have $\mathrm{PhDs}$ in nursing and are experienced in the field of nursing terminology.

\section{Data ANALYSIS AND TREATMENT}

Numerical and percentage distributions of patients' descriptive characteristics, NDs and NIC nursing interventions arevpresented in table form. Agreement between the two researchers on NDs and interventions was determined by using percentages.

\section{ETHICAL ASPECTS}

Ethical approval (opinion number 2016/21-36, protocol number 2772-GOA) was obtained from the Research Ethics Committee of the Faculty of Nursing and from the participating hospital. Participants provided their written informed consent.

\section{RESULTS}

The mean age of patients $(n=54)$ was $59.12 \pm 6.47$ years (min-max $=43-75), 66.7 \%$ were married and $38.9 \%$ were high school graduates. Half of patients were retired and $79.6 \%$ had social security insurance (Table 1 ).

The mean length of hospital stay was $3.38 \pm 0.97$ days $(\min -\max =2-5)$. Antibiotics, antiemetics and analgesic drugs were given to all patients for prophylaxis after the early postoperative period, $20.4 \%$ of patients had food allergies, $46.3 \%$ reported nausea, and $63 \%$ reported dysuria. All patients had a urinary catheter. The mean sleep duration was $5.70 \pm 1.46$ hours/day (min-max $=3-8)$. Pain was reported by $74.1 \%$ of patients, and the mean pain score was $3.62 \pm 2.24$ (min-max $=0-8)$. Also, $22.2 \%$ of patients reported feeling nervous and anxious about the prognosis, and $25.9 \%$ were reluctant to communicate with the staff.

Table 1 - Distribution of men who underwent radical prostatectomy according to age, marital status, education, employment status and social security - İzmir, Turkey, 2016-2017.

\begin{tabular}{lcc}
\hline Demographic Variables & $\mathbf{n}$ & $\%$ \\
\hline Age groups (years) & 9 & \\
$43-53$ years & 35 & 16.7 \\
54-64 years & 10 & 64.8 \\
65-75 years & & 18.5 \\
\hline Marital status & 18 & 33.3 \\
Single & 36 & 66.7 \\
Married & & \\
\hline Education & 20 & 37 \\
Primary school level & 21 & 38.9 \\
High school level & 13 & 24.1 \\
University level & & \\
\hline Employment status & 27 & 50 \\
Pensioner & 7 & 13 \\
Civil servant & 8 & 14.8 \\
Employee & 12 & 22.2 \\
Self-employed & & \\
\hline Social-security & 43 & 79.6 \\
Social security insurance & 11 & 20.4 \\
Self-employed insurance & $\mathbf{5 4}$ & $\mathbf{1 0 0}$ \\
\hline Total & & \\
\hline
\end{tabular}

The mean body mass index of patients was $25.70 \pm 1.92$ (min-max $=21.40-29.75)$. Hyperthermia was observed in seven patients (13\%) in the first postoperative day, and early postoperative hypothermia was seen in three patients. Tibial oedema was detected in $20.4 \%$ of patients and slight pitting oedema (2 $\mathrm{mm}$ depth) was present in ten patients. A high blood glucose level was found in $33.3 \%$ of patients. The level of prostate-specific antigen (PSA) was over $4 \mathrm{ng} / \mathrm{ml}$ in $79.4 \%$ of patients.

The two researchers identified independently $87.6 \%$ agreement between NDs and $81.7 \%$ consistency between the interventions. A total of 1135 NDs were determined. Sixtyseven different NDs were identified in patients with RP.

Nine different NDs were in the class of coping responses, six in physical injury and self-concept, five in self-esteem, and four in hydration and self-care (Table 2).

In patients, were used 22 out of the 30 NIC classes. Thirteen different interventions selected were in the class of coping assistance, ten were in the class of risk management, eight were in the class of elimination management and in the class of nutrition support, and seven in the class of patient education (Table 3). 
Table 2 - Distribution of nursing diagnoses of patients - İzmir, Turkey, 2016-2017.

\begin{tabular}{|c|c|c|c|c|c|}
\hline Domain & Class & Code & Nursing diagnoses & $\mathbf{n}$ & $\%$ \\
\hline Health promotion & Health management & 00099 & Ineffective health management & 15 & 27.8 \\
\hline Nutrition & $\begin{array}{l}\text { Ingestion } \\
\text { Metabolism } \\
\text { Hydration }\end{array}$ & $\begin{array}{l}00233 \\
00234 \\
00179 \\
00195 \\
00025 \\
\end{array}$ & $\begin{array}{c}\text { Overweight } \\
\text { Risk for overweight } \\
\text { Risk for unstable blood glucose level } \\
\text { Risk for electrolyte imbalance } \\
\text { Excess fluid volume }\end{array}$ & $\begin{array}{c}15 \\
7 \\
18 \\
5 \\
11 \\
\end{array}$ & $\begin{array}{c}27.8 \\
13.0 \\
33.3 \\
9.3 \\
20.4 \\
\end{array}$ \\
\hline Activity & $\begin{array}{c}\text { Sleep/rest } \\
\text { Cardiovascular/ } \\
\text { pulmonary responses } \\
\text { Self-care }\end{array}$ & $\begin{array}{l}00108 \\
00109 \\
00102\end{array}$ & $\begin{array}{c}\text { Disturbed sleep pattern } \\
\text { Risk for impaired cardiovascular function } \\
\text { Bathing self-care deficit } \\
\text { Dressing self-care deficit } \\
\text { Feeding self-care deficit }\end{array}$ & $\begin{array}{l}41 \\
39 \\
26\end{array}$ & $\begin{array}{l}75.9 \\
72.2 \\
48.1\end{array}$ \\
\hline Perception/Cognition & Cognition & 00126 & Deficient knowledge & 37 & 68.5 \\
\hline Self- Perception & Self-concept & 00124 & Hopelessness & 6 & 11.1 \\
\hline Coping/stress tolerance & Coping responses & $\begin{array}{l}00146 \\
00069 \\
00148 \\
00241 \\
00125 \\
\end{array}$ & $\begin{array}{c}\text { Anxiety } \\
\text { Ineffective coping } \\
\text { Fear } \\
\text { Impaired mood regulation } \\
\text { Powerlessness } \\
\end{array}$ & $\begin{array}{l}9 \\
9 \\
9 \\
5 \\
7\end{array}$ & $\begin{array}{c}16.7 \\
16.7 \\
16.7 \\
9.3 \\
13.0\end{array}$ \\
\hline Safety/Protection & $\begin{array}{c}\text { Physical injury } \\
\text { Environmental hazards } \\
\text { Thermoregulation }\end{array}$ & $\begin{array}{l}00155 \\
00246 \\
00217 \\
00007 \\
00008\end{array}$ & $\begin{array}{c}\text { Risk for falls } \\
\text { Risk for delayed surgical recovery } \\
\text { Risk for allergy response } \\
\text { Hyperthermia } \\
\text { Ineffective thermoregulation }\end{array}$ & $\begin{array}{c}25 \\
12 \\
11 \\
7 \\
10\end{array}$ & $\begin{array}{l}46.3 \\
22.2 \\
20.4 \\
13.0 \\
18.5\end{array}$ \\
\hline Comfort & Physical comfort & $\begin{array}{l}00134 \\
00132\end{array}$ & $\begin{array}{c}\text { Nausea } \\
\text { Acute pain }\end{array}$ & $\begin{array}{l}25 \\
40 \\
\end{array}$ & $\begin{array}{l}74.1 \\
74.1\end{array}$ \\
\hline
\end{tabular}

Table 3 - Selected NIC interventions for the patients - İzmir, Turkey, 2016-2017.

\begin{tabular}{|c|c|c|c|c|c|}
\hline Domain /Class & Class & Code & NIC Interventions (code) & $\mathrm{n}$ & $\%$ \\
\hline \multirow[t]{11}{*}{ 1.Physiological: Basic } & A. Activity and Exercise & 0180 & Energy management & 12 & 22.2 \\
\hline & Management & 0200 & Exercise promotion & 25 & 46.3 \\
\hline & & 0224 & Exercise therapy: joint mobility & 19 & 35.2 \\
\hline & D. Nutrition Support & 1020 & Diet staging & 12 & 22.2 \\
\hline & & 1050 & Feeding & 26 & 48.1 \\
\hline & & 1100 & Nutrition management & 17 & 31.5 \\
\hline & & 5246 & Nutritional counselling & 19 & 35.2 \\
\hline & & 1260 & Weight management & 20 & 37.0 \\
\hline & & 1280 & Weight reduction assistance & 18 & 33.3 \\
\hline & $\begin{array}{l}\text { E. Physical Comfort } \\
\text { Promotion }\end{array}$ & 1400 & Pain management & 25 & 46.3 \\
\hline & F. Self-care Facilitation & 1610 & Bathing & 41 & 75.9 \\
\hline \multirow[t]{4}{*}{ 2. Physiological: Complex } & H. Drug Management & 2300 & Medication administration & 31 & 57.4 \\
\hline & J. Perioperative Care & 2210 & Analgesic administration & 36 & 66.7 \\
\hline & & 1450 & Nausea management & 25 & 46.3 \\
\hline & M. Thermoregulation & 1380 & Heat/cold application & 22 & 40.7 \\
\hline \multirow[t]{19}{*}{ 3. Behavioural } & O. Behaviour Therapy & 4350 & Behaviour management & 19 & 35.2 \\
\hline & & 4360 & Behaviour modification & 19 & 35.2 \\
\hline & $\begin{array}{l}\text { Q. Communication } \\
\text { Enhancement }\end{array}$ & 4978 & $\begin{array}{c}\text { Communication enhancement: } \\
\text { visual deficit }\end{array}$ & 13 & 24.1 \\
\hline & R. Coping Assistance & 5230 & Coping enhancement & 27 & 50.0 \\
\hline & & 5820 & Anxiety reduction & 26 & 48.1 \\
\hline & & 5250 & Decision-making support & 26 & 48.1 \\
\hline & & 5330 & Mood management & 18 & 33.3 \\
\hline & & 5380 & Security enhancement & 19 & 35.2 \\
\hline & & 5390 & Self -awareness enhancement & 26 & 48.1 \\
\hline & & 5395 & Self-efficacy enhancement & 36 & 66.7 \\
\hline & & 5440 & Support system enhancement & 17 & 31.5 \\
\hline & S. Patient Education & 5602 & Teaching: disease process & 27 & 50.0 \\
\hline & & 5606 & Teaching: Individual & 19 & 35.2 \\
\hline & & 5614 & Teaching: prescribed diet & 21 & 38.9 \\
\hline & & 5616 & $\begin{array}{l}\text { Teaching: prescribed medication } \\
\text { Teaching: procedure/treatment }\end{array}$ & 22 & 40.7 \\
\hline & & 5618 & & 18 & 33.3 \\
\hline & & & Progressive muscle relaxation & & \\
\hline & T. Psychological & 1460 & & 27 & 50.0 \\
\hline & $\begin{array}{l}\text { Comfort } \\
\text { Promotion }\end{array}$ & & & & \\
\hline 4. Safety & V. Risk Management & 4020 & Bleeding reduction & 24 & 44.4 \\
\hline \multirow[t]{3}{*}{ 6. Health System } & Y. Health System & 7040 & Caregiver support & 22 & 40.7 \\
\hline & Mediation & 7370 & Discharge planning & 19 & 35.2 \\
\hline & & 7400 & Health system guidance & 15 & 27.8 \\
\hline
\end{tabular}


The NDs identified for all patients are shown in Table 4.
The NIC interventions identified for all patients are shown in Table 5.

Table 4 - Nursing diagnoses identified in all patients - İzmir, Turkey, 2016-2017.

\begin{tabular}{|c|c|c|c|}
\hline Domain & Class & Code & Nursing Diagnoses \\
\hline Nutrition & Hydration & $\begin{array}{l}00028 \\
00025\end{array}$ & $\begin{array}{l}\text { Risk for deficient fluid volume } \\
\text { Risk for imbalanced fluid volume }\end{array}$ \\
\hline Elimination and Exchange & Urinary function & 00016 & Impaired urinary elimination \\
\hline Activity/Rest & Self-care & 00110 & Toileting self-care deficit \\
\hline Sexuality & Sexual function & 00065 & Ineffective sexuality pattern \\
\hline Life principles & $\begin{array}{l}\text { Value/belief/action } \\
\text { congruence }\end{array}$ & 00184 & $\begin{array}{l}\text { Readiness for enhanced } \\
\text { decision making }\end{array}$ \\
\hline Safety/protection & $\begin{array}{c}\text { Infection } \\
\text { Physical injury } \\
\text { Thermoregulation }\end{array}$ & $\begin{array}{l}00004 \\
00206 \\
00047 \\
00005\end{array}$ & $\begin{array}{l}\text { Risk for infection } \\
\text { Risk for bleeding } \\
\text { Risk for impaired skin integrity } \\
\text { Risk for imbalanced } \\
\text { body temperature }\end{array}$ \\
\hline Comfort & Environmental comfort & 00214 & Impaired comfort \\
\hline
\end{tabular}

Table 5 - NIC interventions identified for all patients - İzmir, Turkey, 2016-2017.

\begin{tabular}{|c|c|c|c|}
\hline Domain & Class & Code & NIC interventions \\
\hline \multirow[t]{4}{*}{$\begin{array}{l}\text { 1.Physiological: } \\
\text { basic }\end{array}$} & B. Elimination management & $\begin{array}{l}0550 \\
1876 \\
0570 \\
0600 \\
0560 \\
0580 \\
0590\end{array}$ & $\begin{array}{l}\text { Bladder irrigation } \\
\text { Tube care: urinary } \\
\text { Urinary bladder training } \\
\text { Urinary habit training } \\
\text { Pelvic muscle exercise } \\
\text { Urinary catheterization } \\
\text { Urinary elimination management }\end{array}$ \\
\hline & D. Nutrition support & $\begin{array}{l}1120 \\
1160\end{array}$ & $\begin{array}{l}\text { Nutrition therapy } \\
\text { Nutritional monitoring }\end{array}$ \\
\hline & E. Physical comfort promotion & 6482 & $\begin{array}{c}\text { Environmental } \\
\text { management: comfort }\end{array}$ \\
\hline & F. Self-care facilitation & $\begin{array}{l}1710 \\
1720 \\
1730 \\
1804 \\
1850 \\
1750\end{array}$ & $\begin{array}{l}\text { Oral health maintenance } \\
\text { Oral health promotion } \\
\text { Oral health restoration } \\
\text { Self-care assistance/toileting } \\
\text { Sleep enhancement } \\
\text { Perineal care }\end{array}$ \\
\hline \multirow[t]{6}{*}{$\begin{array}{l}\text { 2.Physiological: } \\
\text { complex }\end{array}$} & G. Electrolyte and acid-base management & $\begin{array}{l}2020 \\
2080\end{array}$ & $\begin{array}{c}\text { Electrolyte monitoring } \\
\text { Fluid/electrolyte management }\end{array}$ \\
\hline & H. Drug management & 2380 & Medication management \\
\hline & J. Perioperative care & 3902 & $\begin{array}{l}\text { Temperature } \\
\text { regulation: perioperative }\end{array}$ \\
\hline & L. Skin/wound management & 3440 & Incision site care \\
\hline & M. Thermoregulation & 3900 & Temperature regulation \\
\hline & N. Tissue perfusion management & $\begin{array}{l}4010 \\
4190 \\
4200 \\
4130 \\
4140\end{array}$ & $\begin{array}{l}\text { Bleeding precautions } \\
\text { Intravenous (IV) insertion } \\
\text { Intravenous therapy } \\
\text { Fluid monitoring } \\
\text { Fluid resuscitation }\end{array}$ \\
\hline \multirow[t]{4}{*}{ 3. Behavioural } & O. Behaviour therapy & 4470 & Self- modification assistance \\
\hline & Q. Communication enhancement & 4920 & Active listening \\
\hline & R. Coping assistance & $\begin{array}{l}5248 \\
5240\end{array}$ & $\begin{array}{l}\text { Sexual counselling } \\
\text { Counselling }\end{array}$ \\
\hline & S. Patient education & 5612 & Teaching: prescribed exercise \\
\hline \multirow[t]{2}{*}{ 4. Safety } & V. Risk management & $\begin{array}{l}6550 \\
6574 \\
6610 \\
6650 \\
6680\end{array}$ & $\begin{array}{l}\text { Infection protection } \\
\text { Patient identification } \\
\text { Risk identification } \\
\text { Surveillance } \\
\text { Vital signs monitoring }\end{array}$ \\
\hline & Y. Health system mediation & 7460 & Patient rights protection \\
\hline 5. Family & X. Lifespan care & 7110 & Family involvement promotion \\
\hline \multirow[t]{2}{*}{ 6. Health system } & a. Health system management & 7610 & Point of care testing \\
\hline & b. Information management & 7920 & Documentation \\
\hline
\end{tabular}




\section{DISCUSSION}

In this study, we determined the NDs seen in the early postoperative period of patients undergoing $\mathrm{RP}$, and the appropriate NIC interventions before discharge in the light of these NDs.

The vascular nature of the surgical site, postoperative haemorrhage, restricted fluid intake before surgery, and post-obstructive diuresis may lead to fluids and electrolyte imbalance ${ }^{(4)}$. Accordingly, the NDs Risk for deficient fluid volume and Risk for imbalanced fluid volume were present in all patients in the current study. In a study aimed at identifying the defining characteristics and related or risk factors regarding the NDs present in men undergoing prostatectomy, the ND Risk for deficient fluid volume was determined in $94 \%(n=50)$ of patients ${ }^{(21)}$. This finding is consistent with our study.

Mechanical obstruction due to blood clots, oedema, trauma and surgical procedure, pressure and irritation of the catheter or balloon, and loss of bladder tone may be related to the ND Impaired urinary elimination, which was found in all patients in our study ${ }^{(4-5)}$.

Patients who had prostate surgery like RP are at risk of haemorrhage and infection such as urinary tract infection ${ }^{(4-5)}$. Thus, the NDs Risk for infection and Risk for bleeding were detected in all patients in our study. In parallel with our findings, the ND Risk for infection was found in all patients $(n=50)$ in another study ${ }^{(21)}$. In addition to this ND, Risk for impaired skin integrity was determined in all patients in our study. This may be caused by invasive procedures, traumatized tissue or surgical incision.

Patients need to know about what they are expected to do in the recovery process, possible complications and what may be effective in dealing with these problems. In the current study, the ND Deficient knowledge was identified in nearly $70 \%$ of patients. Deficient knowledge was determined in $20 \%(\mathrm{n}=50)$ of patients in a study ${ }^{(21)}$, and findings of another study carried out with patients undergoing urological surgery ${ }^{(22)}$ demonstrated the presence of this ND in $61 \%$ of patients. This difference in proportion of Deficient knowledge might be associated with information previously given to patients in the other study ${ }^{(21)}$, different clinical procedures, and different levels of awareness of Pca and its treatment.

Pain in the postoperative period is a possible outcome after RP, impairs organs functions, delays mobilization, and increases the risk of postoperative complications ${ }^{(23)}$. Accordingly, we found that nearly $75 \%$ of individuals had the ND Acute pain especially in the first day of surgery. Similarly, Acute pain was present in $36 \%(n=50)$ of men in another study ${ }^{(21)}$.

The main negative outcomes of $\mathrm{RP}$ are complications such as urinary incontinence and erectile dysfunction in the medium and late postoperative periods after discharge, which significantly affect the QOL ${ }^{(4-5,24-25)}$. Recent studies have reported the occurrence of urinary incontinence in around $70 \%$ of patients and erectile dysfunction in $68 \%$ of patients ${ }^{(3,6,24)}$. Because our main purpose was to identify the NDs of patients with RP in the immediate postoperative stage, urinary incontinence (also, all patients had urinary catheters) and sexual dysfunction could not be determined. However, the ND Deficient knowledge and the related NIC interventions proposed by researchers such as "Sexual counselling", "Bladder irrigation", "Urinary elimination management" and "Pelvic muscle exercise" were addressed given the possibility of occurrence of these postoperative complications.

In the early postoperative period, patients should be given essential information about care of the operation site, signs and prevention of bleeding and infection, pain management, management of a permanent urinary catheter at home, and the coping with physical side-effects, such as incontinence and erectile dysfunction. If the patient has family or a partner, these should be included in the education $^{(4-7,24-28)}$. As a result of the study, we determined that in accordance with this information and the NDs established, the following NIC interventions were appropriate for all patients: "Active listening", "Counseling", "Infection protection", "Medication management", "Pelvic muscle exercise", "Self-modification assistance", and "Tube care: urinary".

The following NIC interventions were the most determined for patients: "Vital signs monitoring", "Bathing", "Analgesic administration", "Medication administration", "Coping enhancement", "Anxiety reduction", "Decisionmaking support", "Teaching: disease process" and "Feeding". In a study with patients who underwent RP $(n=121)$, researchers ${ }^{(29)}$ identified educational nursing interventions for drug administration and various non-pharmacological interventions namely: emptying the urine bag and measuring the amount of urine in all patients; vital signs evaluation in 99.2\%; bathing in 98.3\%; and urinary catheter management in $16 \%$ of patients about to be discharged. These findings are in line with our study. In the results of that study, were determined various interventions such as, dressing for drain, maintenance of continuous irrigation of PVC, and performing venous puncture. This difference in various interventions may be related to the inclusion of both patients with a diagnosis of Pca and those with benign prostatic hyperplasia, and surgical cases of both partial and total prostatectomy.

Since patients' self-care activities may be restricted in the postoperative period, other important nursing interventions recommended in this study were "Self-care assistance" and "Bathing". In the early postoperative period, many patients are unable to perform self-care activities and need help. "Bathing" was deemed appropriate for patients included in the study, and is an intervention applied to provide patients' comfort and to relieve or remove pain and sleep problems. In another study with similar findings to ours, the intervention "Bathing" was identified for most (98.3\%) patients ${ }^{(29)}$.

As this study was carried out in a single centre and the sample size was small, the findings cannot be generalized to all patients undergoing RP. Nonetheless, the results contribute to the limited previous studies with a similar aim and provide a new insight into the value of nursing care for patients with RP for urology nurses in Turkey. 


\section{CONCLUSION}

This study highlighted the significance of using standardized nursing languages in Turkey. The main NDs demonstrated in our study were in the classes of physical injury, self-care, hydration and physical comfort. In parallel with the NANDA-I NDs identified, the most selected NIC interventions were in the classes of risk management, elimination management, coping assistance, tissue perfusion management and self-care facilitation.

Multicentre studies with larger populations are needed. Additionally, future studies are needed to explore the relationships between NANDA-I NDs and the effects of NIC interventions on these patients.

One of the main concerns is that patients need emotional support and information on their lives after discharge, because the length of hospital stay has decreased recently due to the higher number of RP cases treated with a laparoscopic approach. Comprehensive and individualized nursing care empowered with a holistic and collaborative approach is a key element for coping with post-discharge issues and helps patients affected by physical and psychosocial changes to plan their new life goals, which will lead to men's higher QOL. The partner or spouse of the patient should also be integrated in discharge planning and education to achieve the best outcomes. Follow-up after discharge reduces readmission. Nursing care should be guided by a standardized and systematic approach. In this sense, use of a common language such as NANDA-I NDs and NIC interventions facilitates visible and objective care among nurses. This also ensures permanent communication between nursing professionals.

\section{RESUMO}

Objetivo: Determinar os diagnósticos de enfermagem da NANDA-I e as intervenções de enfermagem (NIC) em pacientes que passaram por prostatectomia radical. Método: um estudo transversal e descritivo foi realizado em um hospital universitário e de pesquisa na Turquia ocidental entre junho de 2016 e junho de 2017. A amostra incluiu pacientes adultos diagnosticados com câncer de próstata no período pós-operatório imediato da prostatectomia radical. A coleta de dados foi realizada usando os padrões funcionais de saúde de Marjory Gordon, NANDA-Internacional e os sistemas de taxonomia para a classificação das intervenções de enfermagem. Resultados: Participaram 54 pacientes adultos. Os principais diagnósticos de enfermagem foram nas classes de "lesão física", "autocuidado", "hidratação" e "conforto físico". Alguns diagnósticos de enfermagem foram identificados em todos os pacientes, especificamente: "risco para volume de líquidos deficiente", "risco para volume de líquidos desequilibrado", "eliminação urinária prejudicada". As intervenções (NIC) mais selecionadas foram nas classes de "manejo de riscos", "manejo da eliminação", "assistência de cobertura", "manejo da perfusão tecidual" e "facilitação do autocuidado". Conclusão: estudos futuros com populações maiores são necessários para explorar os diagnósticos de enfermagem e os efeitos das intervenções de enfermagem em pacientes que passaram por prostatectomia radical.

\section{DESCRITORES}

Prostatectomia; Processos de Enfermagem; Diagnóstico de Enfermagem; Classificação; Enfermagem Oncológica.

\section{RESUMEN}

Objetivo: Determinar los diagnósticos de enfermería de la NANDA-I y las intervenciones de enfermería (NIC) en pacientes que pasaron por prostatectomía radical. Método: Un estudio transversal y descriptivo fue realizado en un hospital universitario y de investigación en Turquía occidental entre junio de 2016 y junio de 2017. La muestra incluyó a pacientes adultos diagnosticados con cáncer de próstata en el período posoperatorio inmediato de la prostatectomía radical. La recolección de los datos se llevó a cabo utilizándose los patrones funcionales del paciente de Marjory Gordon, NANDA Internacional y los sistemas de taxonomía para la clasificación de las intervenciones enfermeras. Resultados: Participaron 54 pacientes adultos. Los principales diagnósticos de enfermería fueron en las clases de "daño físico", "autocuidado", "hidratación" y "comodidad física". Algunos diagnósticos enfermeros fueron identificados en todos los pacientes, específicamente: "riesgo para volumen de líquidos deficiente", "riesgo para volumen de líquidos desequilibrado", "eliminación urinaria perjudicada”. Las intervenciones (NIC) más seleccionados fueron en las clases de "manejo de riesgos", "manejo de la eliminación", "asistencia de cobertura" "manejo de la perfusión tisular" y "facilitación del autocuidado". Conclusión: Estudios futuros con poblaciones más grandes son necesarios para explorar los diagnósticos de enfermería y los efectos de las intervenciones enfermeras en pacientes que pasaron por prostatectomía radical.

\section{DESCRIPTORES}

Prostatectomía; Proceso de Enfermería; Diagnóstico de Enfermería; Clasificación; Enfermería Oncológica.

\section{REFERENCES}

1. Kim CS, Lee JY, Chung BH, Kim WJ, Fai NC, Hakim L, et al. Report of the second Asian Prostate Cancer (A-CaP) Study Meeting. Prostate Int. 2017;5(3):95-103.

2. Zorlu F, Divrik RT, Eser S, Yorukoğlu K. Prostate cancer incidence in Turkey: an epidemiological study. Asian Pac J Cancer Prev. 2014;15(21):912530

3. Lombrana M, Izquierdo L, Gomez A, Alcaraz A. Nursing Care Program for Erectile Dysfunction After Radical Prostatectomy. Clin J Oncol Nurs. 2012;16(5):E178-E82.

4. Ignatavicius DD, Workman ML, editors. Medical-surgical nursing patient-centered collaborative care. New York: Elsevier; 2013.

5. Lemone P, Burke K, Bauldoff G, editors. Medical-surgical nursing critical thinking in patient care. London: Pearson; 2011.

6. King AJL, Evans M, Moore THM, Paterson C, Sharp D, Persad R, et al. Prostate cancer and supportive care: a systematic review and qualitative synthesis of men's experiences and unmet needs. Eur J Cancer Care (Engl). 2015;24(5):618-34. DOI: 10.1111/ecc.12286

7. Mata LRF, Napoleão AA. Nursing interventions for patients discharged from prostatectomy: an integrative review. Acta Paul Enferm. 2010;23(4):574-9.

8. Moore KN, Estey A. The early post-operative concerns of men after radical prostatectomy. J Adv Nurs. 1999;29(5):1121-9. 
9. Şimşir A, Temeltaş G. Radikal retropubik prostatektomi sonrası gelişen idrar kaçırmada çözüm yolları. Üroonkoloji Bulteni. 2011;2:108-11.

10. Birol L, editor. Hemşirelik süreci: hemşirelik bakımında sistematik yaklaşımlar. Estanbul: Etki Yayınları; 2010.

11. Bluchek G, Butcher H, Dochterman J, Wagner C, editors. Nursing interventions classification (NIC). St Louis: Mosby; 2012.

12. Cordova P, Lucero R, Hyun S, Quinlan P, Price K, Stone P. Using the nursing interventions classification as a potential measure of nurse workload. J Nurs Care Qual. 2010; 25(1):39-45.

13. Herdman TH, Kamitsuru S, editors. NANDA International nursing diagnoses: definitions and classification 2015-2017. Oxford: WileyBlackwell; 2014.

14. Johnson M, Moorhead S, Bulechek G, Butcher H, Maas M, Swanson E, editors. NOC and NIC linkages to NANDA-I and clinical conditions supporting critical reasoning and quality care. Oxford: Elsevier; 2012.

15. Scherb C, Weydt A. Work complexity assessment, nursing interventions classification, and nursing outcomes classification: making connections. Creat Nurs. 2009; 15(1):16-22.

16. Kelly M, Sharp L, Dwane F, Kelleher T, Drummond FJ, Comber H. Factors predicting hospital length- of -stay after radical prostatectomy: a population-based study. BMC Health Serv Res. 2013;13:244.

17. Weber JR, Kelley JH, editors. Health assessment in nursing. Lippincott: Williams and Wilkins; 2014.

18. Gordon M. Nursing diagnosis: process and application. St. Louis: Mosby; 1994.

19. Acaroğlu K, Kaya H, editors. NANDA hemşirelik tanıları: tanımlar\& sınıflandırma 2015-2017. İstanbul: Nobel Tıp Kitabevleri; 2017.

20. Erdemir F, Kav S, Yılmaz AA. Hemşirelik girişimleri sınıflaması (NIC). İstanbul: Nobel Tıp Kitabevleri; 2017.

21. Saldanha EA, Medeiros AB, Frazão CM, da Silva VM, Lopes MV, Lira AL. Nursing diagnoses in patients undergoing prostatectomy: identification of the significance of its component. Rev Bras Enferm. 2014;67(3):430-7.

22. Lima WG, Nunes SFL, Alvarez AM, Valcarenghi RV, Bezerra MLR. Principais diagnósticos de enfermagem em idosos hospitalizados submetidos às cirurgias urológicas Rev Rene. 2015;16(1):72-80.

23. Heikkinen K, Salantera S, Kettu M, Taittonen M. Prostatectomy patients' postoperative pain assessment in the recovery room. J Adv Nurs. 2005;52(6):592-600.

24. Eduardo AHA, Napoleao AA, Carvalho EC. Nursing interventions for patients with erectile dysfunction after radical prostatectomy: Integrative review. Emferm Glob. 2016;15(2):456-71.

25. Kong E, Deatrick JA, Bradway CK. Men's experiences after prostatectomy: a meta-synthesis. Int J Nurs Stud. 2017;74:162-71.

26. Cockle-Hearne J, Charnay-Sonnek F, Denis L, Fairbanks HE, Kelly D, Kav S, et al. Faithfull S. The impact of supportive nursing care on the needs of men with prostate cancer: a study across seven European countries. Br J Cancer. 2013;109(8):2121-30.

27. Mata LRF, Silva AC, Pereira MG, Carvalho EC. Telephone follow-up of patients after radical prostatectomy: a systematic review. Rev Latino Am Enfermagem. 2014;22(2):337-45.

28. Rego BFM, Lima CAF, Fernandes MICD, Saldanha EA, Lira ALBC, Vitor AF. Educational steps adopted in post-operative period of prostatectomy: an integrative review. J Nurs UFPE on line. 2014;8(Suppl. 3):4122-30.

29. Mata LRF, Ferreira TC, Carvalho EC. Nursing actions in the perioperative period and in preparing prostatectomy patients for discharge. Invest Educ Enferm. 2013;31(3):406-13. 